\title{
CHARACTERISTICS OF ISLAMIC EDUCATION IN THE PERSPECTIVE OF THE QURAN AND AL-HADITS
}

\section{KARAKTERISTIK PENDIDIKAN ISLAM DALAM PERSPEKTIF AL-QURAN DAN AL-HADITS}

\author{
Lukman Hakim \\ STH Galunggung Tasikmalaya \\ Email: Lukmanhakim3963@gmailcom
}

\begin{abstract}
Formulating the goals of Islamic education must be prioritized before formulating other educational elements. Concern about educational goals is more important than concerns about educational materials or methods because educational materials and methods can change from time to time, while educational goals do not change. It is always constant and does not change. From an Islamic perspective, the purpose of education must be in line with the goal of human creation, namely to serve oneself or worship al-Kholiq Subhanahu Wata'ala and carry out the duties of the caliphate. Worship in Islam reaches to touch all aspects of life. It is not only limited to the rituals (asy-sya'aa'ir), which we are familiar with in prayer, fasting, zakat, and hajj. However, it also includes all movements and all activities that can improve human life quality or prosper human beings. Concerning the relationship with the Rabb of humans, they are servants of Allah. Meanwhile, about the relationship with the universe (kaun), man is the caliph. Therefore, it can be said that human life's purpose is to fulfill servitude and devotion - in a broad sense - to Allah Ta'ala. At the same time, his role on earth is as caliph (leader) in this universe.
\end{abstract}

Keyword: the purpose of education, worship, caliph.

\begin{abstract}
ABSTRAK
Merumuskan tujuan pendidikan Islam harus lebih diprioritaskan sebelum merumuskan unsur-unsur pendidikan yang lain. Perhatian tentang tujuan pendidikan lebih penting dari pada perhatian tentang materi atau metode pendidikan karena materi dan metode pendidikan dapat berubah dari masa ke masa, sedangkan tujuan pendidikan tidak berubah. Ia selalu konstan dan tidak mengalami perubahan. Dalam perspektif Islam, tujuan pendidikan harus selaras dengan tujuan penciptaan manusia yaitu menghambakan diri atau beribadah kepada al-Kholiq Subhanahu Wata'ala dan mengemban tugas kekhalifahan. Ibadah dalam Islam jangkauannya menyentuh semua aspek kehidupan. Tidak hanya terbatas pada ritual-ritual (asy-sya'aa'ir) yang sudah biasa kita kenal berupa shalat, puasa, zakat dan haji. Akan tetapi mencakup pula seluruh gerak dan semua aktivitas yang dapat meningkatkan kualitas kehidupan manusia atau mensejahterakan manusia. Dalam kaitan relasi dengan Rabb-nya manusia adalah hamba Allah. Sedangkan dalam kaitan relasi dengan alam semesta (kaun) manusia adalah khalifah. Oleh karena itu dapat dikatakan bahwa tujuan hidup manusia adalah menunaikan penghambaan dan pengabdian -dalam makna yang luas- kepada Allah Ta'ala. Sedangkan perannya di muka bumi adalah sebagai khalifah (pemimpin) di alam semesta ini.
\end{abstract}

Kata kunci: tujuan pendidikan, ibadah, khalifah. 


\section{A. PENDAHULUAN}

Ada sebuah kaidah fiqih yang berbunyi "al-umuru bimaqosidiha", yakni setiap tindakan dan perbuatan harus berorientasi pada tujuan atau rencana yang telah ditetapkan di awal. Kaidah ini menunjukkan bahwa pendidikan seharusnya berorientasi pada tujuan yang ingin dicapai bukan semata-mata berorientasi pada sederetan materi. Karena itulah, tujuan pendidikan Islam menjadi kompenen pendidikan yang harus dirumuskan terlebih dahulu sebelum merumuskan komponen-kompenen pendidikan yang lain.

Tujuan merupakan standar usaha yang dapat ditentukan, serta mengarahkan usaha yang akan dilalui dan merupakan titik pangkal untuk mencapai tujuan-tujuan lain. Disamping itu, tujuan dapat membatasi ruang gerak usaha, agar kegitan dapat terfokus pada apa yang dicita-citakan, dan yang terpenting lagi adalah dapat memberi penilaian atau evaluasi pada usaha-usaha Pendidikan (Ahmad D. Marimba, 1980; 45-46).

\section{B. TINJAUAN PUSTAKA}

Perumusan tujuan pendidikan Islam harus berorientasi pada hakikat pendidikan yang meliputi beberapa aspek, misalnya tentang:
Pertama, tujuan dan tugas hidup manusia. Manusia hidup bukan karena kebetulan dan sia-sia. Ia diciptakan dengan membawa tujuan dan tugas hidup tertentu. Tujuan diciptakannya manusia hanya untuk mengabdi kepada Allah Subhanahu Wata'ala.

Kedua, memerhatikan sifat-sifat dasar (nature) manusia, yaitu konsep tentang manusia sebagai makhluk unik yang mempunyai beberapa potensi bawaan seperti fitrah, bakat, minat, sifat, dan karakter yang berkecenderungan pada alhanief (rindu akan kebenaran yang datang dari Tuhan) berupa agama Islam.

Ketiga, tuntutan masyarakat. Tuntutan ini baik berupa pelestarian nilai-nilai budaya yang telah melembaga dalam kehidupan suatu masyarakat, maupun pemenuhan terhadap tuntutan kebutuhan hidupnya.

Keempat, dimensi-dimensi kehidupan ideal Islam. Dimensi kehidupan ideal Islam mengandung nilai yang dapat meningkatkan kesejahteraan hidup manusia di dunia untuk mengelola dan memanfaatkan dunia sebagai bekal kehidupan di akhirat, serta mengandung nilai yang mendorong manusia berusaha keras untuk meraih kehidupan di akhirat yang lebih membahagiakan (Abdul Mujib dan Yusuf Mudzakkir, 2006; 71-72). 
Tujuan pendidikan merupakan syarat mutlak dalam mendefinisikan pendidikan itu sendiri yang paling tidak didasarkan atas konsep dasar mengenai manusia, alam dan ilmu serta dengan pertimbangan prinsip-prinaip dasarnya. Sebagian ahli Pendidikan Islam menyebut istilah tujuan pendidikan Islam dengan visi dan misi pendidikan Islam.

Perhatian tentang tujuan pendidikan lebih penting dari pada perhatian tentang sarana pendidikan. Sarana pendidikan pasti berubah dari masa ke masa, dari generasi ke generasi, bahkan dari suatu tempat ke tempat yang lain. Akan tetapi tujuan pendidikan tidak berubah. Ia selalu tetap dan istiqomah. Tujuan pendidikan merupakan masalah sentral dalam proses pendidikan. Hal itu di sebabkan oleh fungsi-fungsi yang dipikulnya, yaitu:

Pertama, tujuan pendidikan mengarahkan perbuatan mendidik. Fungsi ini menunjukkan pentingnya perumusan dan pembatasan tujuan pendidikan secara jelas. Tanpa tujuan yang jelas, proses pendidikan akan berjalan tidak efektif dan tidak efisien, bahkan tidak menentu dan salah dalam mengambil metode, sehingga tidak mencapai manfaat.

Kedua, tujuan pendidikan mengakhiri usaha pendidikan. Apabila tujuannya telah tercapai, maka berakhir pula usaha tersebut. Usaha yang terhenti sebelum tujuan tercapai, maka berakhir pula usaha tersebut. Usaha yang terhenti sebelum tujuannya tercapai, sesungguhnya belum dapat di sebut berakhir, tetapi hanya mengalami kegagalan yang antara lain disebabkan oleh tidak jelasnya rumusan tujuan pendidikan.

Ketiga, tujuan pendidikan di satu sisi membatasi lingkup suatu usaha pendidikan, tetapi di sisi lain memengaruhi usaha dinamikanya. Hal ini disebabkan karena pendidikan merupakan usaha berproses yang di dalamnya usaha-usaha pokok dan usaha-usaha parsial saling terkait. Tiap-tiap usaha memiliki tujuannya masing-masing. Usaha pokok memiliki tujuan yang lebih tinggi dan lebih umum. Sedangkan usaha parsial memiliki tujuan yang lebih rendah dan lebih spesifik (Ahmad D. Marimba, 1980; 45-46).

Menurut Ibn Taimiyah, sebagaimana dikutip oleh Majid 'Irsan al-Kaylani, tujuan pendidikan Islam bertumpu pada empat aspek, yaitu :

1. Tercapainya pendidikan tauhid dengan cara mempelajari ayat-ayat Allah subhanahu wata'ala yang tertuang dalam wahyu-Nya dan juga ayat-ayat pada alam (aafaq) dan psikis (anfus). 
2. Mengetahui ilmu Allah subhanahu wata'ala melalui pemahaman terhadap kebenaran makhluk-Nya.

3. Mengetahui kekuasan (qudrah) Allah subhanahu wata'ala melalui pemahaman jenis-jenis, kuantitas, dan kreativitas makhluk-Nya.

4. Mengetahui apa yang diperbuat Allah subhanahu wata'ala, (sunnah Allah) tentang realitas (alam) dan jenis-jenis perilakunya (Abdul Mujib dan Yusuf Mudzakkir, 2006; 78).

Sedangkan Abdul Rahman Shaleh Abdullah menyatakan bahwa tujuan pendidikan Islam dapat diklasifikasikan menjadi empat dimensi, yaitu :

1. Tujuan Pendidikan Jasmani (al-Ahdaf al-Jismiyah)

Mempersiapkan diri manusia sebagai pengemban tugas khalifah di bumi, melalui keterampilan-keterampilan fisik. Ia berpijak pada pendapat Imam Nawawi yang menafsirkan "al-qawy" sebagai kekuatan iman yang ditopang oleh kekuatan fisik, "Nabi mereka mengatakan kepada mereka: "Sesungguhnya Allah telah mengangkat Thalut menjadi rajamu". Mereka menjawab: "Bagaimana Thalut memerintah kami, padahal kami lebih berhak mengendalikan pemerintahan daripadanya, sedang diapun tidak diberi kekayaan yang cukup banyak?" Nabi (mereka) berkata: "Sesungguhnya Allah telah memilih rajamu dan menganugerahinya ilmu yang luas dan tubuh yang perkasa". Allah memberikan pemerintahan kepada siapa yang dikehendaki-Nya. Dan Allah Maha Luas pemberian-Nya lagi Maha Mengetahui”. (Q.S.Al-Baqarah: 247)

Kemudain dalam Surat Al-Anfal Ayat 60 dijelaskan, "Dan siapkanlah untuk menghadapi mereka kekuatan apa saja yang kamu sanggupi dan dari kudakuda yang ditambat untuk berperang (yang dengan persiapan itu) kamu menggentarkan musuh Allah dan musuhmu dan orang orang selain mereka yang kamu tidak mengetahuinya; sedang Allah mengetahuinya. Apa saja yang kamu nafkahkan pada jalan Allah niscaya akan dibalasi dengan cukup kepadamu dan kamu tidak akan dianiaya (dirugikan).

2. Tujuan Pendidikan Rohani (al-Ahdaf al-Ruhaniyah)

Mensucikan jiwa agar senantiasa taat dan mengabdi hanya kepada Allah subhanahu wata'ala semata serta melaksanakan moralitas Islami yang 
diteladankan oleh Nabi shallallahu 'alaihi wasallam dengan berdasarkan pada cita-cita ideal dalam Al-Qur'an disebutkan yang artinya "Katakanlah: "Inginkah aku kabarkan kepadamu apa yang lebih baik dari yang demikian itu?". Untuk orang-orang yang bertakwa (kepada Allah), pada sisi Tuhan mereka ada surga yang mengalir dibawahnya sungai-sungai; mereka kekal didalamnya. Dan (mereka dikaruniai) isteri-isteri yang disucikan serta keridhaan Allah. Dan Allah Maha Melihat akan hambahamba-Nya.” (Q.S. Ali Imran: 15).

Di antara indikasi kesucian rohani adalah tidak bermuka dua/munafik (Q.S. Al-Baqarah: 10), berupaya memurnikan dan menyucikan diri manusia secara individual dari sikap negatif (Q.S Al-Baqarah: 126); dan inilah yang disebut dengan tazkiyah (purification) dan hikmah (wisdom).

3. Tujuan Pendidikan Intelektual (alAhdaf al- 'Aqliyah)

Pengarahan inteligensi untuk menemukan kebenaran dan sebabsebabnya dengan telaah tanda-tanda kekuasaan Allah dan menemukan pesan-pesan ayat-ayat-Nya yang berimplikasi kepada peningkatan iman kepada Sang Pencipta. Tahapan akal ini adalah:

a. Pencapaian kebenaran ilmiah (ilm al-yaqin) (Q.S. Al-Takastur : 5)

b. Pencapaian kebenaran empiris (ain al-yaqin) (Q.S. Al- Takastur : 7)

c. Pencapaian kebenaran metaempiris atau mungkin lebih tepatnya sebagai kebenaran filosofis (haqq-alyaqin)

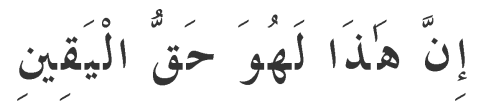

Sesungguhnya (yang disebutkan ini) adalah suatu keyakinan yang benar. (Q.S. Al-Waqi.ah : 95).

4. Tujuan Pendidikan Sosial ( al-Ahdaf al-Ijtima 'iyah)

Tujuan pendidikan sosial adalah pembentukan kepribadian yang utuh yang menjadi bagian dari komunitas sosial. Identitas individu disini tercermin sebagai "an-nas" yang hidup pada masyarakat yang plural (majemuk) (Abdul Mujib dan Yusuf Mudzakkir, 2006; 78).

Dalam khazanah pemikiran pendidikan Islam, pada umumnya para ulama berpendapat bahwa tujuan akhir pendidikan Islam adalah "untuk beribadah kepada Allah Subhanahu wa Ta'ala." Di antara para ulama tersebut misalnya:

Para sarjana muslim yang bertemu di Konferensi Dunia Tentang pendidikan 
Islam, mereka berpendapat, "The ultimate aim of muslim education lies in the realization of comp;ete submission to Allah on the level of the individual, the community and humanity at large." (Tujuan akhir dari pendidikan Islam terletak pada perwujudan penyerahan diri atau ketundukan tidak mutlak kepada Allah pada tingkat individu, masyarakat, dan kemanusiaan pada umumnya) (Muhaimin, 2012; 48).

Abdul Fattah Jalal, dalam bukunya Min Ushul al-Tarbawiyah Fi al Islam, menyatakan bahwa tujuan utama pendidikan Islam adalah mempersiapkan manusia yang beribadah kepada Allah, yaitu manusia yang memiliki sifat-sifat yang diberikan oleh Allah Subhanahu wa Ta'ala kepada ibadurrahman atau hambahamba Allah yang mendapat kemuliaan. Selain itu, Pendidikan Islam juga mampu menletakkan manusia pada tempat yang tinggi kehidupan di dunia (Rahendra Maya, 2017; 1). Mengutip Al-Kilani Rahendra Maya mengungkapkan, bahwa tujuan Pendidikan Islam mengantarkan peserta didik sampai kepada kesempurnaan insani dengan menuntunnya sampai kepada derajat yang baik dan sempurna, sesuai dengan kaidah-kaidah Islam (Rahendra Maya, 2013; 450).
Demikian pula Muhammad Munir Mursyi, dalam bukunya, Al-tarbiyah alIslamiyyah Ushuluha wa Thathawwuruha, menyatakan bahwa pendidikan Islam itu diarahkan kepada peningkatan manusia yang menyembah kepada Allah dan takut kepada-Nya (Muhaimin, 2012; 48).

Dari pemaparan para ahli tersebut dapat kita simpulkan bahwa tujuan pendidikan dalam perspektif Islam tidak terlepas dari tujuan hidup manusia yaitu menghambakan diri atau beribadah kepada Allah Subhanahu Wata'ala dan menunaikan tugas kekhalifahan. Hal ini menuntut kita untuk memahami lebih dalam tentang makna ibadah dalam Islam.

\section{PEMBAHASAN}

\section{Tujuan Pendidikan Islam Mengacu}

\section{Kepada Tujuan Penciptaan Manusia}

Allah Subhanahu wa Ta'ala telah menegaskan bahwa Ia tidaklah menciptakan langit, bumi dan semua yang ada di alam semesta dengan main-main atau tanpa tujuan yang benar. Dan hal ini sangat bertentangan dengan sifat Allah Ta'ala yang Maha bijaksana (al-Hakim).

"Dan Kami tiada menciptakan langit dan bumi dan apa yang ada di antara keduanya melainkan dengan tujuan yang benar dan 
dalam waktu yang ditentukan.”

(Q.S. Al-Ahqaf: 3)

Demikian pula halnya dengan manusia, makhluk yang Allah istimewakan dan telah diberi kelebihan dari sekalian makhluk yang ada. Allah Ta'ala tidaklah menciptakan manusia kecuali untuk sebuah tujuan yang besar dan risalah (misi) yang agung. Mustahil Allah menciptakan manusia tanpa suatu maksud yang urgen. Allah subhanahu wata'ala telah membantah sangkaan yang salah dari sebagian manusia sebagaimana firmanNya:

"Maka apakah kamu mengira, bahwa sesungguhnya Kami menciptakan kamu secara mainmain (saja), dan bahwa kamu tidak akan dikembalikan kepada Kami?" (Q.S. Al Mu'minun : 115).

Tentang tujuan hidup manusia, AlQur'an al-Karim telah memaparkannya dengan sangat jelas. Allah Ta'ala berfirman:

"Dan Aku tidak menciptakan jin dan manusia melainkan supaya mereka beribadah kepada-Ku." (Q.S. Adz-Dariyat: 56)

"Dan mereka tidaklah disuruh kecuali supaya menyembah Allah dengan memurnikan ketaatan
kepada-Nya dalam menjalankan agama yang lurus, dan supaya mereka mendirikan shalat serta menunaikan zakat; dan yang demikian itulah agama yang lurus." (Q.S. Al-Bayyinah: 5)

Tentang surat Adz-Dzariyat ayat 56 di atas, Imam ath-Thabari berkata, "Pendapat yang paling tepat tentang ta'wil ayat ini adalah apa yang kami kutip dari Ibn 'Abbas yaitu, "Tidaklah Kami ciptakan jin dan manusia kecuali untuk menghambakan diri kepada Kami dan merendahkan diri terhadap perintah Kami." (Muhammad bin Jarir At-Thabari, 445).

Sedangkan Al-Bagowi dan sebagian ahli tafsir yang lain memaknai ayat di atas dengan

إلا ليخضعو إليّ ويتذللوا، ومعنى العبادة في اللغة: التذلل و الانقياد "kecuali agar mereka tunduk kepada-Ku dan menghinakan diri." Sedangkan ma'na ibadah secara bahasa adalah kehinaan dan kepatuhan (Al-Husain bin Mas'ud AlBagowi, 381).

Ayat ini menjelaskan dengan gamblang tentang tujuan penciptaan manusia, yaitu beribadah kepada Allah Subhanahu Wata'ala. Kesimpulan ini menuntut kita untuk memahamai lebih dalam tentang makna ibadah itu sendiri. 
Ibrahim Anis mengemukakan, bahwa secara etimologi, kata al-ibadah (العبادة) dalam bahasa Arab merupakan bentuk mashdar dari kata عبد yang memiliki arti:

$$
\text { انقْادَ لَهُه وَخَضَعَ وََلَّلَ }
$$

"patuh terhadapnya, tunduk dan menghinakan diri” (Ibrahim Anis, 579).

Ar-Raghib Al-Ashfahani berkata Ar-Raghib al-Ashfahani mengungkapkan, "Al-'Ubudiyyah bermakna menampakkan kehinaan, sedangkan ibadah lebih dalam lagi karena ia adalah puncak penghinaan diri dan hal ini tidak layak dipersembahkan kecuali kepada Dzat yang memiliki puncak karunia yaitu Allah Ta'ala. Oleh karena itu Allah berfirman:

"Dan Tuhanmu telah memerintahkan supaya kamu jangan menyembah selain Dia." (Q.S. Al-Isra': 23)

Al-Harrani mengungkapkan, adapun secara terminologi, maka sebagian ulama mendefinisikan ibadah dengan:

$$
\begin{aligned}
& \text { اسم جامع لكل ما يحبه الله و يرضاه من الأقو ال } \\
& \text { و الأعمال الباطنة و الظاهرة }
\end{aligned}
$$

"Suatu istilah yang mencakup segala sesuatu yang dicintai Allah dan diridhaiNya, baik berupa perkatan maupun perbuatan, yang tersembunyi (batin), maupun yang nampak (lahir)." (Ahmad ibn Abdul Halim Al-Harrani, 6).
Sedangkan

Al-Manawi

mendefinisikannya:

و العبادة الطاعة مع خضوع وتذلل لله وحلده ، وقيل لغة الخضوع وعرفا فعل المكلف على خلاف هوى نفسه تعظيما لربه Ibadah adalah keta'atan disertai dengan ketundukan dan kerendahan diri kepada Allah semata. Dikatakan pula, secara bahasa bermakna ketundukan (al-khudhu'), sedang secara istilah adalah perbuatan seorang mukallaf yang bertentangan dengan keinginan hawa nafsunya dalam rangka mengagungkan Robb-nya." (Muhammad Abdur Ra'uf-al-Manawi , $1415 ; 701)$.

Definisi-definisi di atas meskipun ungkapannya berbeda, akan tetapi menunjukkan kepada makna yang sama, yaitu penghambaan kepada Allah Ta'ala dengan menunaikan apa saja yang dicintaiNya demi mengaharap ridha dan pahala di sisi-Nya. Hal ini menunjukkan bahwa makna ibadah sangatlah luas. Tidak hanya terbatas pada ritual-ritual khusus saja.

Dengan demikian dapat dikatakan bahwa mendirikan shalat, berzakat, berpuasa, berhaji, ucapan yang jujur, menunaikan amanah, berbakti kepada kedua orang tua, menyambung tali kekerabatan, menepati janji, memerintahkan berbuat ma'ruf, mencegah kemungkaran, jihad melawan kaum kafir 
dan kaum munafik, berlaku baik terhadap tetangga maupun anak yatim dan orang miskin juga terhadap hewan ternak, berdoa, berzikir, membaca Al-Qur'an, dan hal semisal itu merupakan bentuk-bentuk ibadah.

Demikian pula, cinta kepada Allah dan Rasul-Nya, takut kepada Allah, bertaubat kepada-Nya, memurnikan agama hanya untuk-Nya, sabar atas ketetapan-Nya, bersyukur atas segenap nikmat-Nya, ridha atas keputusan-Nya, bertawakal kepadaNya, mengharap rahmat-Nya, takut akan azab-Nya, serta contoh semisal itu merupakan bentuk-bentuk ibadah kepada Allah.

Jadi, ibadah dalam Islam jangkauannya menyentuh semua aspek kehidupan. Tidak hanya terbatas pada ritual-ritual (asy-sya'aa'ir) yang sudah biasa kita kenal berupa shalat, puasa, zakat dan haji. Akan tetapi mencakup pula seluruh gerak dan semua aktivitas yang dapat meningkatkan kualitas kehidupan manusia atau mensejahterakan manusia.

Semua pekerjaan yang bermanfaat yang dilakukan seorang muslim demi pengabdiannya kepada masyarakat, atau menolong personil-personilnya, khususnya mereka yang tergolong kaum dhu'afa' dan papa juga merupakan salah satu bentuk ibadah. Seorang hamba yang telah mewujudkan pengabdian atau ibadahnya kepada Allah semata dan beristiqomah di atas hal ini maka ia berada di atas jalan yang lurus atau shirath al-mustaqiim. Sebagaimana firman Allah Ta'ala:

"Dan hendaklah kamu menyembahKu. Inilah jalan yang lurus”.(Q.S. Yasiin: 61)

Dalam konteks hubungan dengan Rabb-nya manusia adalah hamba Allah. Sedangkan dalam konteks hubungan dengan alam semesta (kaun) ia adalah khalifah. Oleh karena itu dapat dikatakan bahwa tujuan hidup manusia adalah menunaikan penghambaan dan pengabdian -dalam makna yang luas- kepada Allah Ta'ala. Sedangkan perannya di muka bumi adalah sebagai khalifah (pemimpin) di alam semesta ini.

Dalam pandangan Islam manusia adalah makhluk yang istimewa, makhluk yang sangat dimuliakan. Allah subhanahu wata'ala telah mengisimewakan, memuliakan dan mengutamakan manusia di atas makhluk makhluk-Nya yang lain. Diantara bentuk pengistimewaan manusia itu adalah dijadikannya manusia sebagai Khalifah di muka bumi. Allah berfirman:

"Dan ingatlah ketika Tuhanmu berfirman kepada para malaikat, "Sesungguhnya Aku hendak menjadikan seorang khalifah di 
muka bumi." (Q.S. Al-Baqarah:

30)

Islam telah menegaskan kemuliaan manusia dengan menjadikannya sebagai khalifah Allah di atas bumi ini. Ini adalah sebuah kedudukan yang membuat para malaikat bedecak kagum, lantaran kedudukan itu tidak diberikan kepada mereka, tetapi justru diberikan Allah kepada manusia.

"Ingatlah ketika Tuhanmu berfirman kepada para malaikat, "Sesungguhnya Aku hendak menjadikan seorang khalifah di muka bumi." Mereka berkata: "Mengapa Engkau hendak menjadikan (khalifah) di bumi itu orang yang akan membuat kerusakan padanya dan menumpahkan darah, padahal kami senantiasa bertasbih dengan memuji Engkau dan mensucikan Engkau?" Allah berfirman: "Sesungguhnya Aku mengetahui apa yang tidak kalian ketahui." Dan Allah mengajarkan kepada Adam nama-nama (benda-benda) seluruhnya, kemudian mengemukakannya kepada para malaikat lalu berfirman: "Sebutkanlah kepada-Ku nama bendabenda itu jika kalian memang benar!" Mereka menjawab: "Maha suci Engkau, tidak ada yang kami ketahui selain dari apa yang telah Engkau ajarkan kepada kami; Sesungguhnya Engkau-lah yang Maha mengetahui lagi Maha Bijaksana." (Q.S.

\section{Al-Baqarah: 30-33)}

Allah Ta'ala telah menobatkan manusia sebagai khalifah di muka bumi, dan agar manusia mampu menjalankan tugas besar ini Allah telah mengaruniainya akal dan ilmu pengetahuan yang menjadikannya dapat mengungguli para malaikat.

Setelah jelas bagaimana tujuan hidup manusia dalam perspektif Islam maka kita perlu mencermati bagaimana tujuan pendidikan di negeri kita karena pendidikan adalah bagian dari kehidupan secara total. Oleh karena itu, tujuan pendidikan harus selaras dan sejiwa dengan tujuan kehidupan.

Jika kita amati tujuan pendidikan Nasional maka kita dapati Undang-Undang Nomor 20 tahun 2003 tentang Sistem Pendidikan Nasional pasal 3 berbunyi, "Tujuan pendidikan nasional adalah mengembangkan potensi peserta didik agar menjadi manusia yang beriman dan bertakwa kepada Tuhan Yang Maha Esa, berakhlak mulia, sehat, berilmu, cakap, kreatif, mandiri, dan menjadi warga negara yang demokratis serta bertanggung jawab."

Kalimat "mengembangkan potensi peserta didik agar menjadi manusia yang beriman dan bertakwa kepada Tuhan Yang Maha Esa" tentu sudah selaras dengan 
tujuan kehidupan menurut Al-Qur'an yaitu agar beirbadah kepada Allah Subhanahu wa Ta'ala. Hanya saja kalau kita amati praktek dan aplikasi tujuan tersebut dalam pendidikan praktis di kita, maka masih sangat jauh dari konsep yang tercantum dalam pasal tiga di atas. Sehingga dapat penulis katakan bahwa tujuan pendidikan Nasional seperti yang tercantum dalam Undang-Undang Nomor 20 tahun 2003 tentang Sistem Pendidikan Nasional pasal 3 di atas adalah slogan indah akan tetapi kurang faktual.

Hal ini dapat dibuktikan dengan melihat standar keberhasilan pendidikan secara nasional. Pemerintah menetapkan bahwa tolak ukur keberhasilan pendidikan seorang siswa adalah lulus UN atau Ujian Nasional. Ini berarti pemerintah menekankan tujuan pendidikan hanyalah sebatas keberhasilan dalam sisi intelektual saja dan kurang memerhatikan sisi akidah dan akhlak siswa, padahal tidak mungkin seorang peserta didik dapat menjadi manusia yang beriman dan bertakwa kepada Tuhan yang Maha Esa jika tidak dibekali secara cukup dengan pendidikan keimanan dan akhlak.

Sejak tahun 2004 UN diberlakukan secara nasional dan menjadi satu-satunya faktor yang menentukan kelulusan siswa bersangkutan. Dalam argumennya, pemerintah menekankan bahwa UN perlu terus dijalankan untuk meningkatkan kualitas SDM Indonesia agar tidak semakin tertinggal dari negara-negara lainnya. Kemudian, pada awal pelaksanaannya mata pelajaran yang diujikan meliputi bahasa Indonesia, matematika dan bahasa Inggris. Kemudian pada tahun 2009 jumlah mata pelajaran yang diujikan meningkat menjadi enam mata pelajaran yang disesuaikan dengan penjurusan siswa yakni jurusan Bahasa, IPA atau IPS. Di antara keenam mata pelajaran tersebut pendidikan agama tidak termasuk di dalammya.

\section{Dampak dari Pendidikan yang Tidak Bercorak Religius}

Dengan mengamati fenomena pendidikan di negeri kita tidak salah jika dikatakan bahwa pendidikan nasional kita masih bercorak sekular. Di antara ciri pendidikan sekular adalah kurang memperhatikan peran agama dalam penyusunan kurikulum, penyusunan bahan ajar, proses kegiatan belajar mengajar, menentukan standar kelulusan dan sebagainya.

Ibrohim Bafadhol mengungkapkan, bahwa corak pendidikan yang seperti ini tentu akan berdampak buruk, baik disadari atau tidak. Di antara dampak buruk pendidikan yang tidak bercorak religius adalah: 
a. Membuka pintu bagi tumbuhnya keragu-raguan tentang Allah. Ini dikarenakan paham sekularisme tidak menanamkan keyakinan terhadap Allah Sang Pencipta dalam jiwa para siswa, bahkan yang terjadi justru mengajarkan teori yang mengarah kepada atheisme seperti teori evolusi Darwin, teori asal-usul terjadinya alam semesta dan sebagainya (Mani’ Al-Juhani, 1418).

b. Mengaburkan keimanan terhadap perkara-perkara yang ghaib. Dalam sistem sekularisme, seluruh fenomena-fenomena alam dikaji dan dianalisa secara eksperimental dan terlepas dari kekuasaan Ilahi. Di samping itu juga meremehkan perkara-perkara ghaib seperti keimanan kepada hari akhir, pahala, dosa dan sebagainya. Akibatnya, sebagai hasil dari pendidikan yang sekular itu tumbuhlah suatu masyarakat yang tujuan hidupnya adalah kepuasan dunia semata dan mengukur kesuksesan seorang dengan standar materi (Mani' alJuhani, 1418).

c. Membuka pintu lebar-lebar bagi kerusakan akhlak. Sekularisme tidak memandang tabu atau aib pergaulan bebas antara siswa-siswi selama mereka sudah dewasa dan dilakukan dengan pillihan mereka sendiri (Mani' al-Juhani, 1418). Bukti akan hal ini adalah maraknya kenakalan remaja dan dekadensi moral di kalangan para pelajar. Media massa banyak merekam hal ini. Pergaulan bebas atau seks bebas di kalangan anak baru gede $(\mathrm{ABG})$ di kota-kota besar Indonesia sudah sangat mengkhawatirkan. Menurut sebuah survei, lebih dari 40 persen $\mathrm{ABG}$ di kota-kota besar sudah tidak perawan lagi akibat pergaulan bebas (http://www.merdeka.com/peristiw a/5-tempat-persembunyian-abg.html).

d. Terabaikannya pendidikan rohani. Hal ini dikarenakan sekularisme melupakan karakter manusia yang terdiri dari unsur fisik dan psikis, atau jasmani dan rohani. Ia hanya memberikan perhatian besar pada sisi fisik dan tidak peduli dengan tuntutan rohani. Tidak terpenuhinya kebutuhan rohani akan memicu timbulnya kriminalitas dan penyimpangan moral. Penulis mengamati bahwa pelajaran agama yang hanya dua jam pelajaran 
dalam seminggu sama sekali tidak memenuhi kebutuhan siswa akan pembinaan rohani dan keagamaan yang baik. Ditambah lagi, dalam ujian nasional (UN), mata pelajaran agama tidak termasuk dalam mata pejaran yang diujikan, sehingga hal ini membuat para siswa berpandangan bahwa mata pelajaran agama tidak terlalu penting.

e. Pergeseran nilai-nilai dan normanorma. Pendidikan yang sekular berdampak menghapus nilai-nilai dan norma-norma Islami dari jiwa para siswa, lalu mengantinya dengan nilai-nilai Barat. Sebagai contoh, idola dan ketokohan dalam masyarakat Islam teruntuk orangorang yang shalih dan komitmen dengan syari'at, baik mereka para ulama yang rabbani atau para pemimpin yang shalih. Jadi, standar kemuliaan dan keutamaan adalah ketakwaan. Akan tetapi kini, kita dapati dalam masyarakat yang telah tersekularkan, tokoh dan idola yang selalu disorot oleh media massa dan dikagumi oleh masyarakat luas adalah orang-orang yang jusrtu rendah ketakwaannya seperti artis, penyanyi, pelawak dan sebagainya. f. Pendidikan yang dipisahkan dari nuansa religius hanya akan melahirkan berbagai kepincangan dan problem. Seorang psikiater Amerika dalam bukunya yang berjudul Kembali kepada Iman, menekankan pentingnya pendidikan generasi muda dengan nuansa religius. Ia memaparkan kesalahan pendapat sebagian pendidik yang hendak menjauhkan jiwa agama dalam pendidikan anak-anak. Ia mengakui bahwa pendidikan adalah suatu tugas yang amat kompleks dan rumit, terkait dengan banyak faktor. Selain itu, para pendidik memerlukan bantuan luar untuk menanamkan nilai-nilai terpuji ke dalam jiwa anak-anak didiknya. Ia mengkritik para pendidik yang merasa dirinya terpelajar kemudian merasa tidak membutuhkan nilainilai agama, dan mencari sumber baru yang dianggapnya dapat menolong. Mereka pun menemukan psikologi anak. Akan tetapi ilmu ini tidak dapat dipegang sepenuhnya atau dipercaya seratus persen tentang kebenarannya (Yusuf AlQardhawi, 1999; 255).

Ia menekankan pula pentingnya kembali kepada agama dan mengikuti 
cara-cara yang digariskan oleh agama dalam mendidik generasi dan memperbaiki moral mereka. Ia berpendapat bahwa tidak ada jalan yang lebih baik untuk mendidik generasi selain mengucapkan kepada mereka, "Ini baik, karena Allah memerintahkannya. Allah menyukai dan senang kepada yang baik dan akan memberikan balasan surga kepada orang yang berbuat baik. Ini buruk, karena Allah melarangnya. Allah benci dan murka melihatnya, dan nanti akan menyiksa orang yang melakukannya."

Cara yang demikian lebih baik daripada mengatakan, "Ini baik atau buruk, karena begitu pandangan ibu bapak, dan juga pandangan masyarakat..." dan seterusnya. Yang disebut terakhir memiliki kesan sementara, dan kelak anak akan berpendapat bahwa pandangan masyarakat telah berubah seiring dengan perkembangan zaman (Yusuf Qardhawi, 1999; 255).

\section{KESIMPULAN}

Dari uraian makalah di atas ada beberapa kesimpulan penting yang dapat penulis ambil, yaitu pendidikan seharusnya berorientasi pada tujuan yang ingin dicapai bukan semata-mata berorientasi pada sederetan materi. Karena itulah, tujuan pendidikan Islam menjadi kompenen pendidikan yang harus dirumuskan terlebih dahulu sebelum merumuskan komponenkompenen pendidikan yang lain. Tujuan merupakan standar usaha yang dapat ditentukan, serta mengarahkan usaha yang akan dilalui dan merupakan titik pangkal untuk mencapai tujuan-tujuan lain.

Tujuan pendidikan Islam dapat diklasifikasikan menjadi empat dimensi, yaitu : (1) Tujuan Pendidikan Jasmani (alAhdaf al-Jismiyah), yaitu mempersiapkan diri manusia sebagai pengemban tugas khalifah di bumi, melalui keterampilanketerampilan fisik. (2) Tujuan Pendidikan Rohani (al-Ahdaf al-Ruhaniyah), yaitu pensucian jiwa agar senantiasa taat dan mengabdi hanya kepada Allah subhanahu wata'ala semata serta melaksanakan moralitas Islami yang diteladankan oleh Nabi shallallahu 'alaihi wasallam. (3) Tujuan Pendidikan Intelektual (al-Ahdaf al-'Aqliyah), yaitu pengarahan inteligensi untuk menemukan kebenaran dan sebabsebabnya dengan telaah tanda-tanda kekuasaan Allah dan menemukan pesanpesan ayat-ayat-Nya yang berimplikasi kepada peningkatan iman kepada Sang Pencipta. (4) Tujuan Pendidikan Sosial ( al-ahdaf al-ijtima'iyah), yaitu pembentukan kepribadian yang utuh yang menjadi bagian dari komunitas sosial. 
Kemudian, jika kita cermati lebih jauh, sistem pendidikan yang diterapkan di negara kita lebih menekankan tujuan pendidikan sebatas keberhasilan dalam sisi intelektual atau kognitif saja dan kurang memerhatikan sisi akidah dan akhlak murid, padahal tidak mungkin seorang peserta didik dapat menjadi manusia yang beriman dan bertakwa kepada Tuhan yang Maha Esa jika tidak dibekali secara cukup dengan pendidikan keimanan dan akhlak.

\section{DAFTAR PUSTAKA}

Maya, R. (2013). Menuju Pendidikan Islam Berbasis Al-Ittiba'. Edukasi Islami: Jurnal Pendidikan Islam, 6(11).

Maya, R. (2017). Pemikiran Pendidikan Muhammad Quthb tentang Metode Keteladanan (Al-Tarbiyah bi ALQudwah). Edukasi Islami: Jurnal Pendidikan Islam, 2(4).

Al-Ashfahani, Ar-Raghib. (t.t.). Mufradaat Al-Qur'an. al-Maktabah asy-Syamilah.,

Al-Baghowi, Al-Husain bin Mas'ud. (t.t.). Ma'alim At-Tanzil. Riyadh: Dar atThayyibah.

Al-Harrani, Ahmad ibn Abdul Halim. Al'Ubudiyah. Kairo: Maktabah Dar alBalagh.

Al-Juhani, Mani'. (1418 H). Al-Mausu'ah Al-Muyassarah fi Al-Adyan wa AlMadzhahib wa Al-Ahzab AlMu'ashirah. Riyadh: Dar an-Nadwah al-'Alamiyyah.

Al-Manawi, Muhammad Abdur Ra'uf. (t.t.). Faidh Al-Qadir Syarh Al-Jami' Ash-Shaghir. Beirut: Dar al-Kutub al'Ilmiyyah.
Al-Qardhawi, Yusuf. (1999). Merasakan Kehadiran Tuhan. Yogyakarta: Mitra Pustaka.

Anis, Ibrahim. (t.t.). Al-Mu'jam Al-Wasith. Kairo: Dar al-Ma'arif.

At-Thabari Muhammad bin Jarir. (t.t.). Jami' Al-Bayan fi Ta'wil Al-Qur'an. Riyadh: Mu'assasah ar-Risalah.

Bafadhol, Ibrahim. (2017). Sekularisme dan Pengaruhnya dalam Dunia Pendidikan Islam. Edukasi Islami: Jurnal Pendidikan Islam, 4(7).

Marimba, Ahmad D. (1980). Pengantar Filsafat Pendidikan Islam. Bandung: P.T. Al-Ma'arif.

Mudzakkir, Abdul Mujib dan Yusuf. (2006). Ilmu Pendidikan Islam. Jakarta: Kencana Prenadamedia Group.

Muhaimin, et.al,. (2012). Paradigma Pendidikan Islam. Bandung: PT. Remaja Rosdakarya

http://www.merdeka.com/peristiwa/5tempat-persembunyian-abg-.html 
